\title{
The Effect of Capital Structure, Liquidity, and Company Size towards Profitability
}

\author{
Joy Pandapotan*, Noegrahini Lastiningsih \\ Universitas Pembangunan Nasional Veteran Jakarta, Indonesia \\ *Joypandapotan23@gmail.com
}

\begin{abstract}
This study aims to determine the effect of capital structure, liquidity, and company size on profitability in state-owned companies listed on the Indonesian state-owned enterprise website in 2016 2018. This research uses a quantitative approach. This study uses secondary data from company financial and annual report, the sample consists of 65 stated-owned companies. The data analysis technique in this study uses multiple linear regression, classic assumption test, and the hypothesis test consists of the t-test. Based on the results of data analysis known that capital structure has a insignificant negative effect on profitability, liquidity has a significant positive effect on profitability, and company size has a significant negative effect on profitability. The results of this study are expected to be useful for managers in making decisions related to company management, beneficial for investors in choosing investments, and being useful as a reference for further researchers who studying profitability variables.
\end{abstract}

Keywords: Capital structure, liquidity, company size, profitability.

\section{Introduction}

The main objective of a company is to generate revenue, which becomes the indicator of success of a company, from its operational aspect. If a company wishes to maximize its revenue, the company must be able to utilize the resources it possesses, such as the capital required, a place to obtain that capital, as well as good planning regarding the return of capital obtained, which will become revenue. One of the methods to increase revenue is by valuating the capital structure of the company (Abor, 2005). The manager is an agent who is given trust by the principal, or owner of the company, in running the company. Each activity done by the company is very dependent on the decision of the manager. A manager must be able to decide whether the company will continue or halt. Aside from that, if the company is at a halt, the manager must be able to resume it and return the company to its course (Dawar, 2014). This is why a manager must be able to decide the level of revenue that a company wishes to achieve. The agency theory is based on the contractual relationship between the owner and shareholders, with the management or manager. In deciding this, a manager must also decide how the revenue is obtained using available.

Operational (Podile, 2018), in selecting a capital structure, a manager must take caution to not take the wrong step and also be able to maximize revenue so that it is equivalent to the capital's rate of return. Aside from capital structure, a manager must also have responsibility over the decisions taken to run the company, as well as how much revenue is generated, which will measure the size of the company (Mule et al., 2015). Development in developing countries such as Indonesia focuses more on its economic development, due to the economic underdevelopment. Development in the field of economics greatly supports the achievement of changes and renewals in other sectors. This process does not occur instantly, but requires a relatively long time, through various consistent methods and efforts, in order to promote the welfare of Indonesian citizens. One of the actions that support national development in the field of economics is the creation of State-Owned Enterprises (BUMN/SOEs), in which this planned change increases Indonesia's revenue nationally. This is also one of the policies made by the government to decrease social discrepancies, and promote the welfare of the people (UU RI 19, 2003).

One of the issues in SOEs is in the sector of agriculture, forestry, and fishery, which are prone to losses since the performance of the companies are not satisfactory. This is explained in the financial performance report of SOEs in 2018, in which this particular sector obtained the lowest score regarding the ability of the company to generate revenue and pay off liabilities (Rika, 2019). Aside from this sector, there are many other SOEs who have many issues, especially in the company's finances. There are also SOEs that went bankrupt due to the company's inability to generate revenue, which also affects the company's ability to pay off its liabilities. Due to this, in SOEs, the existence of profitability in supporting operational needs and the goal of the company is fundamental. This is due to the fact that SOEs were created for two purposes, which is to 
generate revenue as a company, as well as improve the national economy and the people's welfare as a driving force for the economy in Indonesia (PP No 12-13, 1998). This is the basis of the execution of this study, which is to measure the effects of capital structure, liquidity, and company size towards the profitability of State-Owned Enterprises (SOEs).

\section{Literature Review}

Theory: This study utilizes the agency theory. The agency theory is based on the contractual relationship between the owner and shareholders, with the management or manager. According to this theory, the relationship between the owner and manager is intrinsically complicated due to the conflict of interest between the two parties (Aswar, 2019). An agency relationship presents itself in the agency theory when one or more parties (principal's party) employs another party (agent's party) in providing a service (service to run the company), and afterwards delegate authorities in all decision making in the entity to the agent. In order to create a smooth contractual relationship, the principal delegated decision-making authority to the agent, and this relationship must be arranged in a contract, which is usually based on the accounting numbers attached in the financial report. Conflicts of interest are the basis of the agency theory, in which contracts are designed to ensure the consistency of the agent's and principal's interest (Cole \& Scott, 2000). The agency theory has a close relationship with profitability, since the main objective of a company is to generate revenue, in which revenue originates from the operational activities if the company, which is run by the manager (agent), according to the instructions of the owner shareholders (principal).

Therefore, a manager must be able to maximize the company's profitability in order to improve the quality of the company, to benefit all parties related to the company, including the manager itself, in which its duties as an agent affects the increase of bonuses for the agent itself. An example of this is using the manager's decision for the capital structure of the company. If the manager is not cautious in benefiting this, then the revenue goal that is expected will not be achieved because of wrong steps taken from the decision of the manager. The agent is also responsible for the company's decision in choosing, borrowing, and also paying back liabilities that are used as the drivers of the company's operations. The ability of a manager in controlling these aspects can cause the company to have a good liquidity rate, which will increase the trust of creditor banks towards the company, should the company choose to borrow again to the creditor. A company is rated well if it can benefit from these aspects, and the more assets a company has in regards to its revenue as well as the ability of managers to control liabilities and the company's capital, then the company's size will increase. The larger the size of the company, the higher the quality of the agent. This is the reason why agents are fundamentally influential in the increasing of a company's profitability.

Hypothesis Development: Profitability is often used as the basis in assessing a company in its financial performance aspect, since revenue is the essence of every business, and without it, a business will be lifeless. After research and hypothesis testing, the researcher concludes several results from the hypothesis testing. Therefore, the development of hypothesis in this study is based on factors that are suspected to have an effect towards the increase and decrease the profitability rate of the company.

Capital Structure: In a company, capital is a fundamental item in the operational function of the company. Without capital, a company cannot exist. Capital structure is a significant management decision since it significantly affects the return of owner's equity, risk, and market value of shares. Due to this fact, the management must increase the capital structure which should be relevant and in line with the company's operations. A previous study conducted by Salawu (2007) concluded that the effect of capital structure towards profitability in Nigerian companies show that there is a positive correlation between profitability and capital structure. An increase in the value of capital structure will increase profitability. This is a logical assumption for the positive relationship between capital structure and profitability. Therefore, the first hypothesis of this study is:

H1: Capital structure has a significant and positive effect towards profitability.

Liquidity: Liquidity is a company's capacity to met financial commitments, which must be fulfilled immediately. Liquidity plays a significant role in assessing a company's efficacy, and therefore, a company must maintain a sufficient liquidity ratio in order to meet its short-term liabilities, because liquidity affects 
the trust of the public. Alagathurai (2013) has proven the significant and positive relationship between liquidity and profitability in commercial companies registered in the stock market in Sri Lanka for 5 years, from 2008-2012. Zygmunt (2013) also explained the important role of the liquidity ratio on the performance of a company, having shown the positive and significant effect of the liquidity ratio towards the profitability of companies in Poland registered in information technology. The more liquid a company is, therefore the quality of the company's finance is better, and therefore has a positive effect towards the ability of a company in generating revenue. This is a logical assumption for the positive relationship between liquidity and profitability. Therefore, the second hypothesis of this study is:

H2: Liquidity has a significant and positive effect towards profitability.

Company Size: Company size can generally be defined as the comparison of size of an object, or a company size is one of the comparisons of the size of an organization or company. Therefore, company size can measure or determine the value of company size. The more assets a company has, the larger the revenue that can be generated, since assets are used by companies for operational activities with the objective of obtaining revenue. In a study on profitability in Sri Lankan hotels and travel sector companies in the period 2008-2012, Sritharan (2016) explained that company size positively effects profitability. When the company size on assets increases, the operations of the company as well as its profitability will also increase. This is a logical assumption for the positive relationship between company size and profitability. Therefore, the third hypothesis of this study is:

H3: Company size has a significant and positive effect towards profitability.

Leverage: Leverage as a control variable. The leverage ratio is used to measure the proportion of the company that uses debt to collect funds (Brigham \& Houston, 2007). In other words, the company uses more of its debt to collect funding for business activities, compared to using its own capital. The higher the ratio of debt on equity, the lower the profitability (Ulzanah \& Murtaqi, 2015).

\section{Research Methodology}

A sample is part of the amount and characteristics possessed by the population. The samples were chosen related to the profitability generated by the company, and can provide the required information. The samples taken in this study are SOEs that are registered in the Indonesian SOE website, which totals to 68 companies, with criteria that the companies have been audited for the 2016-2018 period. The reasoning behind the usage of SOEs as samples in this study is to fully represent issues related to profitability in SOEs. This is because not all SOEs have a good profitability rate, which indicates that the company is not in good health.

Table 1: Study Sample Criteria

\begin{tabular}{ll}
\hline Criteria & Number of Companies \\
\hline State-Owned Enterprises & 115 \\
Incomplete publication of financial reports & 50 \\
Amount of companies & 65 \\
Period of study & 3 \\
Amount of study samples & 195 \\
Outlier & $(27)$ \\
Amount of study samples after outliers & 168 \\
\hline
\end{tabular}

The dependent variable used in this study is profitability. This study uses the profitability ratio measured using return of equity (ROE), which was used by Rajakumaran and Yogendrarajah (2015). The independent variables used in this study are capital structure, liquidity, and company size. Capital structure ratio measured with the debt ratio (DR), which was used in a previous study by Rajakumaran and Yogendrarajah (2015). Liquidity ratio measured by the current ratio (CR), which was used in a previous study by Ahmad (2016). Company size used the natural logarithm from the total assets (SIZE) of the company as the measurement of company size, as was used in a previous study by Kartikasari and Merianti (2016). This study uses the leverage ratio as the control variable, the leverage ratio is the ratio used to evaluate debt and equity by comparing debt and equity, as was done in a previous study by Ulzana and Murtaqi (2015). 


\section{Empirical Findings and Discussion}

Descriptive Analysis: Table 2 represents the calculation and the descriptive statistical data processing result for each variable in the study.

Profitability: The average value (mean) of profitability (ROE) is 0.11 with a standard deviation of 0.078 , which shows that the average (mean) is larger than the standard deviation, with $0.11>0.078$, which means that profitability has a high distribution and fluctuation. The SOE with the highest profitability is PT Telekomunikasi Indonesia in 2017, with a maximum value of 0.29 or revenue of $29 \%$ of the total equity of the company in that period. Meanwhile, the SOE with the lowest profitability rate is PT Krakatau Steel in 2018, with a minimum value of -0.10 or $10 \%$ of its revenue is negative out of its equity. This result shows that PT Telekomunikasi Indonesia in 2017 had a much better profitability compare to PT Krakatau Steel in 201, which had a sub-zero profitability, which means that for every 1.000 Rupiah from the shareholder's equity, PT Telekomunikasi Indonesia in 2017 was able to manage it to generate a profit of 290 Rupiah. Meanwhile, PT Krakatau Steel in 2018 had a negative profitability, which means that every 1.000 Rupiah from the shareholder's equity, PT Krakatau Steel in 2018 experienced a revenue loss of 100 Rupiah. Collectively, the return on equity value in the SOEs studied in this research had an average value of 0.1081 , which means that for every 1.000 Rupiah from shareholder's equity, SOEs were able to manage it to generate 108 Rupiah revenue.

Capital Structure: The average value (mean) of capital structure (DR) is 0.51 with a standard deviation of 0.021 , which shows that the average (mean) is larger than the standard deviation, with $0.51>0.021$, which means that capital structure (DR) has a high distribution and fluctuation. The SOE with the highest capital structure (DR) is PT Bank Rakyat Indonesia in 2018, with a maximum value of 0.86. Meanwhile, the SOE with the lowest capital structure (DR) rate is PT Biofarma in 2016, with a minimum value of 0.10 . The two companies with the maximum and minimum value in this study have a good ratio of debt towards total assets, due to the fact that PT Biofarma in 2016 had a debt to total asset ratio of less than 0,5 , which means that $90 \%$ of the company's assets can be financed by the company through equity. Meanwhile, PT BRI in 2018 had a relatively high debt ratio of 0.86 , which means that $86 \%$ of the company's assets are financed through debt. This is reasonable, due to the fact that debt in the banking sector originates from cash or investments placed by clients towards the bank in the form of savings, in which the savings are liabilities for the bank and that savings in any form are considered as assets in banking companies. Collectively, the value of debt to total asset ratio in SOEs studied in this research has an average value of 0.51 , which means that majority (51\%) of the assets of SOEs are financed through liabilities.

Liquidity: The average value (mean) of liquidity is 1.81 with a standard deviation of 0.973 , which shows that the average (mean) is larger than the standard deviation, with $1.81>0.973$, which means that liquidity has a high distribution and fluctuation. The SOE with the highest liquidity is PT Pelabuhan Indonesia II in 2016, with a maximum value of 5.95. Meanwhile, the SOE with the lowest liquidity is PT Hotel Indonesia Natour in 2016, with a minimum value of 0.38 . The higher the current ratio, the higher the liquidity of a company. The result of the current ratio at present accepts the value of 2, and a current ratio of less than 1 shows that PT Hotel Indonesia Natour (Persero) in 2016 experienced difficulties in fulfilling its current liabilities. However, although PT Pelabuhan Indonesia II in 2016 had a current ratio of 5.95 (>2), it may not show that the company has good finances, since it is possible that the company does not allocate its current assets in effectively managing its capital. Collectively, the value of current ratio in the SOEs studied in this research, has an average value of 1.81, which means that the majority of the SOEs have good liquidity (CR $>1$ ), although not satisfactory enough since the average value is still below 2 .

Company Size: The average value (mean) of company size is 30.03 with a standard deviation of 2.134, which shows that the average (mean) is larger than the standard deviation, with $30.03>2.134$, which means that company size has a high distribution and fluctuation. The SOE with the highest company size ratio is PT Perusahaan Listrik Negara in 2018, with a maximum value of 34.94. Meanwhile, the SOE with the lowest liquidity is PT Indra Karya in 2017, with a minimum value of 25.78. This result shows that PT Perusahaan Listrik Negara in 2018 had the largest assets or resources among all of the SOEs studied in this research. Meanwhile, the SOE with the smallest company size ratio is PT Indra Karya in 2017 with a minimum value of 
25.78. This shows that PT Indra Karya in 2017 is the company with the lowest asset value among all of the SOEs studied in this research.

Leverage: The average value (mean) of leverage (DER) is 1.54 with a standard deviation of 1.405 , which shows that the average (mean) is larger than the standard deviation, with $1.54>1.405$, which means that the leverage variable (DER) has a high distribution and fluctuation. The SOE with the highest debt to equity ratio is PT Bank Negara Indonesia in 2018, with a maximum value of 6.08. Meanwhile, the SOE with the lowest debt to equity ratio is PT Biofarma in 2016, with a minimum value of 0.12 . Generally, the debt to equity ratio that can be tolerated ranges from 1.5 until 2. The debt to equity ratio of PT Biofarma of 0.12 , which is under 1 , indicates that PT Biofarma has a lower rate of debt compared to the company's equity. This can become a recommendation for investors to purchase shares in PT Biofarma.

Table 2: Descriptive Statistics

\begin{tabular}{llllll}
\hline Variables & N & Min & Max & Mean & Std. Deviation \\
\hline ROE & 168 &,- 10 &, 29 &, 10 &, 078 \\
DR & 168 &, 10 &, 86 &, 51 &, 021 \\
CR & 168 &, 38 & 5,95 & 1,81 &, 973 \\
SIZE & 168 & 25,78 & 34,94 & 30,03 & 2,134 \\
DER & 168 &, 12 & 6,08 & 1,54 & 1,405 \\
Valid N (listwise) & 168 & & & & \\
\hline
\end{tabular}

The value of the determinant coefficient (R2) shows how much the variance percentage of the independent variables used in the research model is able to explain the variance of the dependent variable. The following is the result from the determinant coefficient testing between the variables of capital structure, liquidity, and company size, towards the profitability variable, before and after the leverage variable was inputted as a control variable. Table 3 explains that the $\mathrm{R}$ square before the input of the control variable into the study Is 0.071, which means that the independent variables in this study can only explain the profitability variable for 7.1\%. After the variable control was input in the study, the R Square increased to 0.101 . Therefore, it can be concluded that the ability of the independent variables, which are capital structure, liquidity, and company size, along with leverage as a control variable, is able to explain the profitability variable from $10.1 \%$, and the remainder is explained by other variables.

Table 3: Determinant Coefficient (R2)

\begin{tabular}{lll}
\hline $\mathbf{R}$ & R Square & Std. Error of the Estimate \\
\hline, $267 \mathrm{a}$ &, 071 &, 07598 \\
, $318 \mathrm{~b}$ &, 101 &, 07498 \\
\hline
\end{tabular}

Table 4 shows the analysis result of double linear regression. The objective is to use the values of the independent variables to predict the value of the dependent variable. This study was conducted in order to identify the direction of the relationship of the variables of capital structure, liquidity, and company size, towards the profitability variable, which is controlled by leverage as a control variable.

Table 4: Double Linear Regression Analysis

\begin{tabular}{|c|c|c|c|c|c|}
\hline \multirow{2}{*}{ Variables } & \multicolumn{2}{|c|}{ Unstandardized Coefficients } & \multirow{2}{*}{$\begin{array}{l}\text { Standardized } \\
\text { Coefficients } \\
\text { Beta }\end{array}$} & \multirow{2}{*}{$\mathbf{t}$} & \multirow{2}{*}{ Sig. } \\
\hline & B & Std. Error & & & \\
\hline (Constant) & ,255 & ,092 & & 2,773 & ,006 \\
\hline Debt_Ratio &,- 063 & ,062 &,- 166 & $-1,014$ & ,312 \\
\hline Current_Ratio & ,017 & ,007 & ,208 & 2,424 & 016 \\
\hline Size &,- 006 & ,003 &,- 161 & $-2,033$ & 044 \\
\hline Debt_to_Equity_Ratio & ,020 & 009 & ,363 & 2,330 & ,021 \\
\hline
\end{tabular}

Table 5 summarizes the result of hypothesis testing in this study using the partial regression analysis ( $\mathrm{t}$-Test) between the variables of capital structure, liquidity, and company size, towards the profitability variable, with 
leverage as the control variable. The regression equation shows that the $\mathrm{X} 1$ variable (Debt Ratio) and X3 (SIZE) has a negative effect, and the X2 variable (Current Ratio) has a positive effect, towards variable $\mathrm{Y}$ (Profitability), with the leverage variable (DER) as the control variable. The regression equation also proves that all independent variables in this study collectively have a positive effect towards profitability. The normality test shows that the data in this study are normally distributed. Aside from that, the regression model is also free of multicollinearity, heteroscedasticity, and autocorrelation.

Table 5: Summary of Hypothesis Testing Result

\begin{tabular}{lll}
\hline Hypothesis & Result \\
\hline H1 & Capital structure has a positive and significant effect towards profitability & Rejected \\
H2 & Liquidity has a positive and significant effect towards profitability & Accepted \\
H3 & Company size has a positive and significant effect towards profitability & Rejected \\
\hline
\end{tabular}

In Table 4, the partial regression test results show that capital structure, measured using the debt to total asset ratio (DR), and has a negative and insignificant effect. Based on the $t_{\text {calculated }}$ value for the capital structure variable of -0.142 which is negative $(-1.014<1.97462)$, and also the significance value of 0.312 $(0.312>0.05)$, it can be concluded that capital structure, measured using the debt to total asset ratio (DR), has a negative and insignificant effect towards return on equity (ROE). The first hypothesis is rejected. Although the result of this study is negative and insignificant, this result is in line with previous research conducted by Rajakumaran and Yogendrarajah (2015), which showed that $44 \%$ of the total assets of trade companies in Sri Lanka, is represented by debt, and based on the correlation analysis, the debt to total asset ratio (DR) has a negative correlation with return on equity (ROE). The result of this study is not in line with the study conducted by Salawu (2007), which stated that there is a positive effect between capital structure, measured using short-term liabilities, and profitability. The result of this study also differs from the study conducted by Al-Ajlouni and Shawer (2013), which stated that there is a positive and significant relationship between debt ratio (DR) and return on equity (ROE), in petrochemical companies in Saudi Arabia in the 20082011 period.

This difference in result is caused by the difference in the object and period of study. The partial regression test results show that liquidity (CR), has a positive and significant effect towards profitability. Based on the $\mathrm{t}_{\text {calculated }}$ value for the liquidity variable of 2.424 which is positive $(2.424>1.97462)$, and the significance value of $0.016(0.016<0.05)$, it can be concluded that liquidity, measured using current ratio (CR), has a positive and significant effect towards return on equity (ROE). The second hypothesis is accepted. The result of this study is in line with previous research conducted by Ahmad (2016), which studied the profitability and liquidity in the banking sector in Pakistan, which stated that there is a positive relationship between liquidity and profitability. The result of this study is also in line with previous research conducted by Alagathurai (2013), which proved the positive and significant relationship between liquidity and profitability in commercial companies registered in the Sri Lankan stock market from 2008 until 2012, and supports the study conducted by Zygmunt (2013), which stated the positive and significant effect of liquidity ratio towards profitability in companies in Poland that are registered in information technology.

The results show that company size, measured using natural logarithm of total assets (SIZE) has a negative and significant effect towards profitability. Based on the $t_{\text {calculated }}$ value for the company size variable of -2.033 which is negative $(-2.033<1.97462)$, and the significance value of $0.044(0.944>0.05)$, it can be concluded that company size, measured using natural logarithm of total assets (SIZE), has a negative and significant effect towards return on equity (ROE). The third hypothesis is rejected. The result of this study supports previous research conducted by Abeyrathna and Priyadarshana (2019), which conducted research towards 20 manufacturing companies in Colombo, whose results show that the value of company size on total assets has a negative and significant effect towards profitability. However, the result of this study is not in line with previous research conducted by Sritharan (2016), which stated that company size has a positive effect towards profitability, in hotel and travel sector companies in Sri Lanka in the 2008-2012 period. This study is also not in line with previous research conducted by John and Adebayo (2013), which stated that there is a positive effect between company sizes towards profitability, in manufacturing companies in Nigeria for the 2005-2012 period. This difference in result is caused by the difference in the object and period of study. 


\section{Conclusion and Recommendations}

This study empirically investigates the relationship between capital structure (DR), liquidity (CR), and company size (SIZE), towards profitability (ROE), with leverage (DER) as the control variable. This study used 68 State-Owned Enterprises in the years 2016-2018. After research and hypothesis testing, the researcher concludes several results from the hypothesis testing. The result of the first hypothesis proved that capital structure, measured using the debt to total assets ratio (DR), and has a negative and insignificant effect towards profitability. The researcher concluded that companies with a high debt to total asset ratio (DR) will decrease the profitability of a company. Inversely, the decrease of debt to total asset ratio (DR) will increase profitability. Although every industry has different evaluations to determine their capital structure, the researcher concludes that if the debt to total assets ratio (DR) is high, then the ability of the company in generating revenue will experience a decrease. The result of the second hypothesis proved that liquidity, measured using the current ratio (CR), has a positive and significant effect towards profitability. This means that if the current ratio (CR) experiences an increase, then the profitability of the company will also increase.

Although there were several companies in this study whose profitability experienced a decrease when the current ratio (CR) increased, the researcher concludes that as a whole, the data of SOEs in this study, shows that if the current ratio (CR) experiences an increase, therefore the profitability of the company will also increase. Furthermore, if the current ratio (CR) of a company is too low, or experiences a decrease, then the profitability will also decrease. The result of the third hypothesis proved that company size has a negative and significant effect towards profitability. This means that if the company size increases, then the profitability of the company will experience a decrease. Although there were several companies in this study whose profitability experienced a decrease when the company size increased, the researcher concludes that, the data of SOEs in this study, shows that if the natural logarithm of the company's total assets (SIZE) experiences an increase, therefore the profitability of the company will experience a decrease. This study is not without limitations that were experienced. One of the limitations is that the data used by the researcher was not complete due to the limited number of samples that the researcher was able to reach.

This is due to time and financial constraints, since the researcher was only able to collect data from SOE websites, and was not able to gather data from SOEs that did not publish their financial reports. In relation to the conclusion of this study, the researcher provides several recommendations for the next researcher who will study the same subject in this study, in hopes to give benefit. SOEs are advised to be wiser in choosing a suitable capital structure for its company, and must also focus on its company's ability in paying off current debts on current assets that they possess. Companies must be able to increase their liquidity rate in order to put the company in a good financial condition. SOEs must also be cautious when experiencing an increase in total assets, since the ability of the company in generating revenue will not be maximum otherwise. The next researcher is expected to be able to use samples from all SOEs and use a longer observation period in order to be able to generalize the profitability rate of a company. Aside from that, the next researcher is also expected to add other factors as independent variables, in hopes to be able to explain, predict, and study the profitability variable.

\section{References}

Abeyrathna, S. P. G. M. \& Priyadarshana, A. J. M. (2019). Impact of firm size on profitability (Special reference to listed manufacturing companies in Sri Lanka). International Journal of Scientific and Research Publications, 9(6), 561-564.

Abor, J. (2005). The Effect Of Capital Structure On Profitability: An Empirical Analysis Of Listed Firms In Ghana, The Journal of Risk Finance, 6(5), 438-445.

Ahmad, R. (2016). A study of relationship between liquidity and profitability of standard chartered bank Pakistan: analysis of financial statement approach. Global Journal of Management and Business Research: C Finance, 16(1), Version 1.0.

Alagathurai, A. (2013). A nexus between liquidity \& profitability: A study of trading companies in Sri Lanka. European Journal of Business and Management, 5(7), 221-237. 
Al-Ajlouni, A. \& Shawer, M. (2013). The effect of capital structure on profitability: evidence from the petrochemical companies in the Kingdom of Saudi Arabia. International Journal of Research in Commerce, IT \& Management, 3(11), 56-63.

Aswar, K. (2020). Financial performance of local governments in Indonesia. European Journal of Business and Management Research, 4(6), 1-6.

Brigham, E. F. \& Houston, J. F. (2007). Fundamentals of Financial Management (11 ${ }^{\text {th }}$ Ed.). US: South-Western College Publishing.

Cole, R. E. \& Scott, W. R. (2000). The quality movement \& organization theory. Sage Publications, Incorporated.

Dawar, V. (2014). Agency theory, capital structure and firm performance: some Indian evidence, Managerial Finance, 40(12), 1190-1206.

Jensen, M. C. \& Meckling, W. (1976). Theory of the firm: Managerial behavior, agency costs and ownership structure. Journal of Finance Economics, 3(4), 305-360.

John, A. O. \& Adebayo, O. (2013). Effect of firm size on profitability: Evidence from Nigerian manufacturing sector. Prime Journal of Business Administration and Management (BAM), 3(9), 1171-1175.

Kartikasari, D. \& Merianti, M. (2016). The effect of leverage and firm size to profitability of public manufacturing companies in Indonesia. International Journal of Economics and Financial Issues, 6(2), 409-413.

Mule, R. K., Mukras, M. S. \& Nzioka, O. M. (2015). Corporate size, profitability and market value: An econometric panel analysis of listed firms in Kenya, European Scientific Journal, 11(13), 376-396.

Peraturan Pemerintah (PP). (1998). Tahun 1998 Tentang Perusahaan Perseroan (Persero). Lembaran Negara Republik Indonesia Nomor, 15(12).

Peraturan Pemerintah (PP). (1998). Tahun 1998 Tentang Perusahaan Umum (PERUM). Lembaran Negara Republik Indonesia Nomor, 15(13).

Podile, V. (2018). Profitability analysis of a micro enterprise-A case study of Laxmi Vinay Poly Print Packs Private Limited, ZENITH International Journal of Multidisciplinary Research, 8(11), 252-263.

Rajakumaran, T. \& Yogendrarajah, R. (2015). Impact of capital structure on profitability evidence from selected trading companies in Colombo stock exchange, Sri Lanka. International Journal in Management and Social Science, 3(8), 469-479.

Rika, H. (2019). Sri Mulyani Ungkap BUMN Pertanian Rentan Bangkrut. https://www.cnnindonesia.com/ekonomi/20191202194547-92-453506/sri-mulyani-ungkapbumn-pertanian-rentan-bangkrut, (diakses tanggal 1 Januari 2020)

Salawu, R. O. (2007). An empirical analysis of the capital structure of selected quoted companies in Nigeria. The International Journal of Applied Economics and Finance, 1(1), 16-28.

Sritharan, V. (2016). Does firm size influence on firm's profitability? Evidence from listed firms of Sri Lankan hotels and travels sector. Research Journal of Finance and Accounting, 6(6), 201-207.

Ulzanah, A. A. \& Murtaqi, I. (2015). The impact of earnings per share, debt to equity ratio, and current ratio towards the profitability of companies listed in LQ45 from 2009 to 2013. Journal of Business and Management, 4(1), 18-27.

Undang-Undang Republik Indonesia (UU). (2003). Nomor 19 Tahun 2003 tentang Badan Usaha Milik Negara. Lembaran Negara Republik Indonesia. Tahun 70 (2003).

Zygmunt, J. (2013). Does liquidity impact on profitability? A case of Polish listed it companies. Conference of Informatics and Management Sciences, Section, 4, 247-251. 